UDC 617.753.2-053.5:681.3

DOI: $10.21668 /$ health.risk/2020.4.08.eng

Read

online

Research article

\title{
LONG USE OF DIGITAL DEVICES AS A RISK FACTOR THAT CAUSES MYOPIA OCCURRENCE IN SCHOOLCHILDREN
}

\section{O.M. Filkina, E.A. Vorobyova, N.V. Dolotova, O.Yu. Kocherova, A.I. Malyshkina}

V.N. Gorodkov's Ivanovo Scientific Research Institute for motherhood and childhood, 20 Pobedy Str., Ivanovo, 153045, Russian Federation

Use of digital devices results in much higher health risks for children caused by greater visual and static loads, low physical activity, intensified intellectual activity, and psychological discomfort.

The article focuses on results obtained in examining reasons why schoolchildren from the $1^{\text {st }}, 5^{\text {th }}, 9^{\text {th }}$, and $11^{\text {th }}$ grade use various digital devices, how frequently they do it and for how long they use mobiles, PC, pads, or laptops. All schoolchildren use digital devices, most frequently, mobile phones and PC. Almost $3 / 4$ children in the $1^{\text {st }}$ grade use a mobile phone; half of them, a PC, 1/3 use a pad; and each fifth schoolchild uses a laptop. Practically all $5^{\text {th }}$ grade children use a mobile phone; two thirds, a PC; half of them, a laptop or a pad. Also practically all senior schoolchildren use a mobile phone; three quarters, a PC; one third, a laptop; pads are used much less frequently. A number of used digital devices per 1 person grows with age, from 1.8 for $1^{\text {st }}$ grade children to 2.6 for $5^{\text {th }}$ grade children and 2.3 for senior schoolchildren. Average duration of digital devices use per day also grows from 3 hours for $1^{\text {st }}$ grade children to 8.1 hours for senior schoolchildren.

Most schoolchildren tended to have diseases of the eye, namely refraction and accommodation disorders; accommodation disorders prevailed among $1^{\text {st }}$ grade children, and myopia was more frequent among $5^{\text {th }}$ grade children and senior schoolchildren. A number of children with myopia grows by 2.1 times during school years. Relative risk calculation revealed that if digital devices are in use for 6 hours or longer, it results in 1.8 times higher risks of myopia.

Key words: schoolchildren, questioning, digital devices, duration of use, eyesight disorders diagnostics, diseases of the eye, myopia, relative risk.

Electronic digital devices play a significant positive role in our everyday life as they have become our irreplaceable assistants in many spheres [1]. In this era of information technologies children start using various digital devices in early childhood [2-5]. With their parents' permission children get acquainted with information technologies in their childhood years and impacts exerted by IT on children's life become more and more intense as they grow up [2]. On the one hand, when children master digital skills, it makes for development of intellectual component in their human potential. Children who use digital appliances tend to have better developed thinking skills, memory, attention, imagination, and digital competences [1-2]. On the other hand, computers, laptops, pads, mobile phones, and smartphones do not bring only benefits; they can also produce negative effects on human health, especially when it comes to a growing person [6-9]. At present there are practically no wide-scale national studies that focus on the issue.

(C) Filkina O.M., Vorobyova E.A., Dolotova N.V., Kocherova O.Yu., Malyshkina A.I., 2020

Olga M. Filkina - Doctor of Medical Sciences, Professor, Honored RF Physician, Honored RF Scientist, Head of the Department for Children's Health Protection (e-mail: omfilkina@mail.ru; tel.: +7 (903) 888-91-94; ORCID: https:// orcid.org/0000-0003-2228-748X).

Elena A. Vorobyova - Doctor of Medical Sciences, Leading researcher at the Department for Children's Health Protection (e-mail: ivniideti@mail.ru; tel.: +7 (909) 249-88-44; ORCID: https://orcid.org/0000-0003-2820-9714).

Natal'ya V. Dolotova - Candidate of Medical Sciences, Senior researcher at the Department for Children's Health Protection (e-mail: dolotovan@inbox.ru; tel.: +7 (903) 879-17-05; ORCID: https://orcid.org/0000-0002-2449-0580).

Olga Yu. Kocherova - Doctor of Medical Sciences, Leading researcher at the Department for Children's Health Protection (e-mail: ivniideti@mail.ru; tel.: +7 (961) 246-24-41; ORCID: https://orcid.org/0000-0002-2473-8339).

Anna I. Malyshkina - Doctor of Medical Sciences, Professor, Director (e-mail: ivniimid@inbox.ru; tel.: +7 (4932) 33-62-63; ORCID: https://orcid.org/0000-0002-1145-0563). 
Digital environment brings about a substantial increase in health risks for children related to greater visual and static loads, low physical activity, intensified intellectual activities, and psychological discomfort [6, 10-12]. Lifestyle pursued by children nowadays differs significantly from that of previous generations as it is characterized with low physical activity, shorter amounts of time spent outdoors, and a lot of study [11]. All this, together with active use of gadgets and digital devices, effects produced by new hygienic factors, and permanent exposure to electromagnetic radiation creates risks of mental and physical health disorders [12]. Uncontrollable use of digital devices often results in bad body posture, poorer eyesight, headaches, increased blood pressure, poorer attention concentration, psychoemotional strain, and gadget-dependency [13-18]. Use of laptops during lessons in primary school does not provide a possibility to maintain a proper working posture for a child even if furniture conforms to all safety requirements related to pupils' height. It results in greater risks of visual disorders and disorders of the musculoskeletal system [19].

Duration and correct use of digital devices in educational process at schools is standardized and children are involved in different kinds of activities during a lesson; this diversity helps reduce negative effects on health [19-22]. There are safety parameters for schoolchildren work with electronic resources fixed in relevant regulations [19]. There is an integral hygienic assessment procedure used for assessing a child's working posture when he or she works with a PC and a procedure for determining whether visual fatigue has occurred in a schoolchild $[19,21]$. But such activities are not regulated at all when children use digital devices at home during their free time [2-3].

If we want to assess effects produced by digital devices on children's health, we have to analyze time spent by them using such devices and try to determine whether children from different age groups use such devices for different periods of time. A.A. Shabunova and A.V. Korolenko established that the highest health index values occurred in children who used a PC or a smartphone rather rarely and it indicates that it is necessary to control frequency and periods of time spent by children on use of digital devices [2].

In a contemporary society eye disorders in children are considered to be one of the most significant medical and social problems. At present, «myopia epidemic» concept is widely used in Russia. When children start school, $2.4 \%$ of them are already short-sighted. By the $5^{\text {th }}$ grade a share of short-sighted children grows by 8 times, reaching $19.7 \%$. By the $11^{\text {th }}$ grade, myopia frequency among schoolchildren is close to European levels and amounts to $36.8 \%$ [14]. There are a lot of research works on risks of myopia development in childhood and a great amount of them are published by foreign authors [14, 17-18]. Some experts have examined effects produced by digital devices, PC or a mobile phone in particular, on children's eyesight [6-7, 14, 17-18]. When parents pay attention to visual activities performed by their children, it can result in significantly lower risks of myopia development. Control over use of electronic digital devices leads to a more than 2-time decrease in risks of myopia development for children [14].

Our research goal was to characterize use of various digital devices and determine risks caused by their long use and related to eye diseases occurrence in children during their school years.

Data and methods. We questioned 140 first-grade pupils, 170 fifth-grade students, and 204 senior schoolchildren (9-11 grades) who attended secondary schools in Ivanovo; questioning was aimed at determining frequency, duration, place and purpose of using various digital devices. We also performed certain examinations in order to diagnose visual disorders in these schoolchildren; our examinations involved autorefractometry, visual acuity test, and non-direct ophthalmoscopy. Data were statistically processed with conventional variation statistics procedures using licensed applied software packages «Microsoft Office 2010» and «Statistica for Windows 6.0». Discrepancies were considered to be statistically authentic at $p<0.05$. We used licensed 
«OpenEpi 303» software program to calculate relative risk (RR). Relative risk is used to compare probability of an outcome depending on a risk factor occurrence. RR is used in studies when examined groups are made up depending on whether a risk factor is present or absent. In case a RR value exceeds 1 , a conclusion is made that a risk factor increases frequency of an outcome (a direct relation).

Results and discussion. Questioning revealed that all the first-grade pupils frequently used digital devices. A mobile phone $(71.4 \%)$ and a PC (51.4\%) were used more frequently than a pad $(35.6 \%)$ and a laptop (18.6\%) (Table 1).

$45.7 \%$ first-grade pupils used a mobile phone every day; $18.6 \%, 2-3$ times a week; $5.7 \%$, once a week; $1.4 \%$, less than once a week. $18.6 \%$ first-grade pupils used a mobile phone for less than 1 hour during a day; $25.7 \%$, for 1 hour; $24.3 \%$, for $2-4$ hours; $2.9 \%$, for longer than 6 hours. All children stated that they used a mobile phone at home; beside that, $5.7 \%$ used it at school and $4.3 \%$ at other places. Firstgrade pupils most frequently used a mobile for games (78\%); watching short clips (51\%); communication $(30 \%)$; searching for information $(20 \%)$; painting $(18 \%)$; reading $(6 \%)$; modeling and animation (6\%). 28.6\% firstgrade students didn't use a mobile phone at all.

Half of first-grade pupils $(51.4 \%)$ used a PC; $12.9 \%$ out of them did it every day; $18.5 \%, 2-3$ times a week; $7.1 \%$, once a week; $12.9 \%$, less than once a week. $24.3 \%$ firstgrade pupils used a PC for less than 1 hours a day; $15.7 \%$, for 1 hour; $10.0 \%$, for $2-4$ hours; $1.4 \%$, for more than 6 hours. All children stated that they used a PC at home; besides, $1.4 \%$ children sued it elsewhere. First-grade pupils used a PC most frequently for watching movies or short clips $(58.3 \%)$ and games $(55.6 \%)$; less frequently for painting $(25 \%)$, searching for information $(22.2 \%)$, communication $(5.6 \%)$, information input $(5.6 \%)$, modeling and animation $(2.8 \%)$, and creating presentations $(2.8 \%) .48 .6 \%$ first-grade pupils didn't use a PC at all.

One third of first-grade pupils (35.6\%) used a pad; $15.7 \%$ out of them did it every day; $7.1 \%, 2-3$ times a week; $1.4 \%$, once a week; $11.4 \%$, less than once a week. $11.4 \%$ first-grade pupils used a pad for less than 1 hours a day; $11.4 \%$, for 1 hour; $10.0 \%$, for 2-4 hours; $1.4 \%$, for more than 6 hours. $96 \%$ first-grade pupils stated that they used a pad at home; besides, $4 \%$ children sued it elsewhere. First-grade pupils used a PC most frequently for games $(92 \%)$, watching movies or clips (40\%), and painting (40\%); less frequently for searching for information (28\%), communication ( $8 \%)$, modeling and animation $(8 \%)$, reading $(4 \%)$, and information input $(4 \%)$. $64.4 \%$ first-grade pupils didn't use a PC at all.

First-grade pupils used a laptop much less frequently than other digital devices $(18.6 \%)$. There were no first-grade pupils who used a laptop every day; $5.7 \%$ used it 2-3 times a week; $4.3 \%$, once a week; $8.6 \%$, less than once a week. $10.0 \%$ first-grade pupils used a laptop for less than 1 hour a day; $8.6 \%, 1$ hour. $92.3 \%$ children stated they used a laptop at home, and $7.7 \%$ did it elsewhere. First-grade pupils used a laptop most frequently for watching movies or short clips $(69.2 \%)$ and games (38.5\%); less frequently, for searching for information $(23.1 \%)$, painting $(23.1 \%)$, communication $(7.7 \%)$, and reading $(7.7 \%) .81 .4 \%$ first-grade pupils didn't use a laptop at all.

Table 1

Frequency of digital devices use by schoolchildren (\%)

\begin{tabular}{|l|c|c|c|c|c|c|}
\hline \multirow{2}{*}{ Digital device } & \multicolumn{2}{|c|}{$\begin{array}{c}\text { grade } \\
(n=140)\end{array}$} & \multicolumn{2}{c|}{$\begin{array}{c}\text { grade } \\
(n=170)\end{array}$} & \multicolumn{2}{c|}{$\begin{array}{c}\text { 9-11 grades } \\
(n=204)\end{array}$} \\
\cline { 2 - 7 } & use & don't use & use & don't use & use & don't use \\
\hline Mobile phone & 71.4 & 28.6 & 97.6 & 2.4 & 98.1 & 1.9 \\
\hline PC & 51.4 & 48.6 & 69.1 & 30.9 & 77.4 & 22.6 \\
\hline Pad & 35.6 & 64.4 & 48.2 & 51.8 & 18.6 & 81.4 \\
\hline Laptop & 18.6 & 81.4 & 49.4 & 50.6 & 33.7 & 66.3 \\
\hline
\end{tabular}


Fifth-grade students used digital devices more intensely than first-grade ones $(p<0.001)$. They also used a mobile phone (97.6\%, $p<0.001)$ and a PC $(69.1 \%, p<0.05)$ more frequently than a pad $(48.2 \%, p>0.05)$ or a laptop $(49.4 \%, p<0.001)$.

$80.0 \%$ fifth-grade students used a mobile phone every day; $12.9 \%, 2-3$ times a week; $4.7 \%$, once a week. $7.1 \%$ fifth-grade students used a mobile phone for less than 1 hour during a day; $22.4 \%$, for 1 hour; $42.3 \%$, for $2-4$ hours; $5.8 \%$, for 4-6 hours; and each fifth student $(20 \%)$ used it for longer than 6 hours a day. $95.2 \%$ fifth-grade students stated that they used a mobile phone at home; beside that, more than half of them (56.6\%) used it at school and $47 \%$ at other places. Fifth-grade students most frequently used a mobile for games (75.9\%); communication (74.7\%); searching for information $(73.5 \%)$; watching short clips (62.7\%); less frequently, for reading (45.8), painting (22.9\%); information input $(18.1 \%)$, creating presentations $(16.9 \%)$, and modeling and animation (8.4\%). $2.4 \%$ fifth-grade students didn't use a mobile phone at all.

Two thirds of fifth-grade students $(69.1 \%)$ used a PC; each forth of them ( $25 \%)$ did it every day; each fifth $(20.2 \%), 2-3$ times a week; $10.7 \%$, once a week; $13.1 \%$, less than once a week. $17.6 \%$ fifth-grade students used a PC for less than 1 hours a day; $27 \%$, for 1 hour; $16.5 \%$, for $2-4$ hours; $5.9 \%$, for $4-6$ hours; $2.4 \%$, for more than 6 hours. Most fifth-grade students $(93.2 \%)$ stated that they used a PC at home; besides, $25.4 \%$ children used it at school and $3.4 \%$ at other places. Fifth-grade children used a PC most frequently for searching for information $(72.9 \%)$, watching movies or short clips $(54.2 \%)$, games $(49.2 \%)$, and creating presentation $(40.7 \%)$; less frequently, for reading $(27.1 \%)$, communication $(23.7 \%)$, painting $(15.3 \%)$, information input $(13.6 \%)$, and modeling and animation (5.1\%). One third of fifthgrade $(30.9 \%)$ students didn't use a PC at all.

Half of fifth-grade students $(48.2 \%)$ used a pad; $23.5 \%$ out of them did it every day; $8.2 \%, 2-3$ times a week; $7.1 \%$, once a week; $9.4 \%$, less than once a week. $9.4 \%$ fifth-grade students used a pad for less than 1 hours a day;
$20 \%$, for 1 hour; $15.3 \%$, for $2-4$ hours; $3.5 \%$, for more than 6 hours. $95.1 \%$ fifth-grade students stated that they used a pad at home; $12.2 \%$ did it elsewhere. Fifth-grade children used a pad most frequently for games $(78 \%)$ and searching for information $(51.2 \%)$; less frequently, for reading and painting (29.3\% each activity), communication $(22 \%)$, watching movies and short clips $(19.5 \%)$, information input $(7.3 \%)$, and creating presentations $(2.4 \%) .51 .8 \%$ fifthgrade students didn't use a pad at all.

Also half of fifth-grade students (49.4\%) used a laptop. $4.7 \%$ out of them did it every day; $17.6 \%, 2-3$ times a week; $11.8 \%$, once a week; $15.3 \%$, less than once a week. $16.5 \%$ fifth-grade students used a laptop for less than 1 hours a day; $20 \%$, for 1 hour; $8.2 \%$, for $2-4$ hours; $3.5 \%$, for 4-6 hours; $1.2 \%$, for more than 6 hours. Most fifth-grade students $(97.6 \%)$ stated that they used a laptop at home; $2.4 \%$ did it at school and $4.8 \%$, elsewhere. Fifthgrade children used a laptop most frequently for searching for information (61.9\%), watching movies and short clips (52.4\%), games (45.2\%), and creating presentations $(40.5 \%)$; less frequently, for reading $(21.4 \%)$, communication and information input (19\% each activity), and painting $(14.3 \%) .50 .6 \%$ fifth-grade students didn't use a laptop at all.

Senior students attending 9-11 grades also used a mobile phone (98.1\%) and a PC (77.4\%) more frequently, but they used a laptop and a pad significantly less frequently than fifth-grade students $(33.7 \%, p<0.05$ and $18.6 \%$, $p<0.001$, accordingly). Practically all senior schoolchildren used a mobile phone every day $(92.3 \%) ; 4.9 \%, 2-3$ times a week; $0.9 \%$, once a week. $1.9 \%$ senior schoolchildren used a mobile phone for less than 1 hour during a day; $5.9 \%$, for 1 hour; one third (30.1\%), for 2-4 hours; $26.2 \%$, for 4-6 hours; and one third (34\%) used it for longer than 6 hours a day. As opposed to first-grade pupils and fifthgrade students, senior schoolchildren used a mobile phone everywhere; $95.1 \%$ did it at home, $80.2 \%$ at school and elsewhere. Senior schoolchildren most frequently used a mobile for searching for information $(92.1 \%)$, communication (86.1\%), and watching short clips 
(66.3\%); less frequently, for reading $(57.4 \%)$, games $(43.6 \%)$, information input $(43.6 \%)$, creating presentations $(11.9 \%)$, painting $(5 \%)$, and modeling and animation (2.9\%). $1.9 \%$ senior schoolchildren didn't use a mobile phone at all.

Two thirds of senior schoolchildren $(77.4 \%)$ used a PC; more than one third of them $(39.2 \%)$ did it every day; each fifth $(20.6 \%)$, 2-3 times a week; $4.9 \%$, once a week; $12.7 \%$, less than once a week. $16.5 \%$ senior schoolchildren used a PC for less than 1 hours a day; $10.7 \%$, for 1 hour; one forth $(25.2 \%)$, for 2-4 hours; $12.6 \%$, for $4-6$ hours; and $12.6 \%$, for more than 6 hours. Most senior schoolchildren $(93.6 \%)$ stated that they used a PC at home; besides, $26.5 \%$ used it at school and $12.7 \%$ at other places. Senior schoolchildren used a PC most frequently for searching for information $(89.8 \%)$, creating presentations $(67.1 \%)$, watching movies or short clips $(65.8 \%)$, and communication $(60.8 \%)$; less frequently, for games $(50.6 \%)$, information input $(35.4 \%)$, reading $(30.4 \%)$, modeling and animation (7.6\%), and painting (2.5\%). $22.6 \%$ senior schoolchildren didn't use a PC at all.

One third of senior schoolchildren $(33.7 \%)$ used a laptop; $10.8 \%$ did it every day; $14.9 \%$, 2-3 times a week; $3 \%$, once a week; $5 \%$, less than once a week. $9.7 \%$ senior schoolchildren used a laptop for less than 1 hours a day; $7.8 \%$, for 1 hour; $11.7 \%$, for $2-4$ hours; $1.9 \%$, for $4-6$ hours; and $3.9 \%$, for more than 6 hours. All senior school-children stated that they used a laptop at home; besides, $17.6 \%$ used it elsewhere. Senior schoolchildren used a laptop, just like a PC, most frequently for searching for information $(85.8 \%)$, watching movies or short clips $(58.8 \%)$, communication $(55.9 \%)$, and creating presentations $(41.2 \%)$; less frequently, for games $(35.3 \%)$, information input $(20.6 \%)$, reading (17.6\%), and painting, modeling and animation (5.9\% each activity). Two thirds of senior schoolchildren $(66.3 \%)$ didn't use a laptop at all.

Senior schoolchildren used a pad much less frequently $(18.6 \%) ; 6.9 \%$ did it every day; $5.9 \%, 2-3$ times a week; $0.9 \%$, once a week; $4.9 \%$, less than once a week. $4.9 \%$ senior schoolchildren used a pad for less than 1 hours a day; $3.9 \%$, for 1 hour; $5.8 \%$, for 2-4 hours; $0.9 \%$, for $4-6$ hours; and $2.9 \%$, for more than 6 hours. All senior school-children stated that they used a pad at home; besides, $15.8 \%$ used it at school and $21.1 \%$ elsewhere. Senior schoolchildren used a pad most frequently for searching for information $(57.9 \%)$, communication $(47.4 \%)$, reading and games $(42.1 \%$ each activity); less frequently, for watching movies or clips $(31.6 \%)$, creating presentations $(10.5 \%)$, and information input $(5.3 \%)$. Most senior schoolchildren $(81.4 \%)$ didn't use a pad at all.

Therefore, when it comes to a specific digital device, school children use a mobile phone or a PC more frequently than a laptop or a pad. Almost $3 / 4$ first-grade pupils use a mobile phone, and half of them use a PC; each fifth also uses a laptop. On average each firstgrade pupil uses 1.8 digital devices, predominantly a mobile phone, and an average time spent by a child on using digital devices amounts to 3 hours a day. Practically all fifthgrade students use a mobile phone; two thirds, a PC, half of them, a laptop or a pad. On average each fifth-grade student uses 2.6 digital devices, and average time spent by him or her on using various digital devices amounts to 6.3 hours a day. Practically all senior schoolchildren also use a mobile phone; $3 / 4$ teenagers use a PC; one third, a laptop; a pad is rather rare. On average each senior schoolchild uses 2.3 digital devices and average time spent by him or her on using various digital devices amounts to 8.1 hours a day. A number of used digital devices grows with age, from 1.8 for first-grade pupils to 2.6 for fifth-grade students and 2.3 for senior schoolchildren. Average time spent on using digital devices per day also grows from 3 hours for first-grade pupils to 8.1 hours for senior schoolchildren.

Complex ophthalmologic examination revealed that diseases of the eye and adnexa were rather frequent among schoolchildren (Table 2).

$100 \%$ first-grade pupils had diseases of the eye and adnexa. Refraction and accommodation disorders were the most frequent $(98.4 \%)$ with 
Table 2

Frequency of detected diseases of the eye and adnexa among schoolchildren (\%)

\begin{tabular}{|l|c|c|c|c|c|}
\hline \multicolumn{1}{|c|}{ Diseases of the eye and adnexa } & $\begin{array}{c}\text { ICD-10 } \\
\text { code }\end{array}$ & $\begin{array}{c}1 \text { grade } \\
(n=126)\end{array}$ & $\begin{array}{c}5 \text { grade } \\
(n=168)\end{array}$ & $\begin{array}{c}9-11 \text { grades } \\
(n=198)\end{array}$ & $p_{1-3}$ \\
\hline & & 1 & 2 & 3 & \\
\hline Inflammation of eyelids (blepharitis) & H 01.0 & - & 1.2 & - & \\
\hline Lacrimal gland disorders & H 04.1 & - & 1.2 & 2.0 & \\
\hline Heterophoria & H 50.5 & - & 1.2 & - & \\
\hline $\begin{array}{l}\text { Refraction and accommodation } \\
\text { disorders including: }\end{array}$ & H 52 & 98.4 & 84.4 & 93.0 & \\
\hline - hypermetropia & H 52.0 & 12.7 & 13.1 & 1.0 & $p=0.0015$ \\
\hline - myopia & H 52.1 & 17.4 & 32.1 & 36.5 & $p=0.0098$ \\
\hline - astigmatism & H 52.2 & 14.3 & 8.3 & 20.2 & $p>0.05$ \\
\hline - anisometropia and aniseikonia & H 52.3 & 1.6 & 8.3 & 3.0 & $p>0.05$ \\
\hline - accommodation disoredrs & H 52.5 & 52.4 & 22.6 & 32.3 & $p=0.0111$ \\
\hline Visual disturbances including: & H 53 & 1.6 & 10.8 & 3.0 & \\
\hline - amblyopia ex anopsia & H 53.0 & - & - & 1.0 & \\
\hline - subjective visual disturbances & H 53.1 & 1.6 & 10.8 & 2.0 & $p>0.05$ \\
\hline Total with pathologies & & $\mathbf{1 0 0}$ & $\mathbf{9 8 . 8}$ & $\mathbf{9 8 . 0}$ & \\
\hline Without pathologies & & - & $\mathbf{1 . 2}$ & $\mathbf{2 . 0}$ & \\
\hline
\end{tabular}

prevailing accommodation disorders (52.4\%). Besides, $17.4 \%$ children had myopia; 14.3, astigmatism; $12.7 \%$, hypermetropia; $1.6 \%$, anisometropia and anisekonia. $1.6 \%$ first-grade pupils had visual disturbances, in particular, subjective visual disturbances.

$98.8 \%$ fifth-grade students had diseases of the eye and adnexa. They also most frequently suffered from refraction and accommodation disorders $(84.4 \%)$ with prevailing myopia (32.1\%). 22.6\% fifth-grade students had accommodation disorders: $13.1 \%$ suffered from hypermetropia; $8.3 \%$, from astigmatism, and $8.3 \%$ from anisometropia and aniseikonia. Besides, $1.2 \%$ fifth-grade students had inflammation of eyelids (blepahritis); $1.2 \%$, lacrimal gland disorders; $1.2 \%$, heterophoria; $10.8 \%$, subjective visual disturbances.

$98 \%$ senior schoolchildren had diseases of the eye and adnexa. As it was the case with first-grade students and fifth-grade ones, refraction and accommodation disorders were the most frequent $(93 \%)$ with prevailing myopia (36.55). 32.3\% senior schoolchildren had accommodation disorders; $20.2 \%$, astigmatism; $3 \%$, anisometropia and aniseikonia; $1 \%$, hypermetropia. Besides, $2 \%$ senior schoolchildren had lacrimal gland disorders; $3 \%$ had visual disturbances such as amblyopia ex anopsia $(1 \%)$ and subjective visual disturbances $(2 \%)$.

Therefore, a number of children with myopia grew by 2.1 times during school years $(p=0.0098)$, hypermetropia frequency went down by 12.7 times $(p=0.0015)$, and accommodation disorders frequency, by 1.6 times $(p=0.0111)$. Dynamics revealed in diseases of the eye and adnexa frequency among fifthgrade students was a bit ambiguous against first-grade pupils and senior schoolchildren. Astigmatism was 1.7 times less frequent in the $5^{\text {th }}$ grade than in the $1^{\text {st }}$ one; however, it became 2.5 times more frequent among senior schoolchildren. Accommodation disorders frequency followed the same trends as it fell by 2.3 times among fifth-grade students in comparison with first-grade ones and then grew by 1.4 times among senior schoolchildren. Anisometropia and aniseikopenia frequency, in its turn, grew by 5.3 times among fifth-grade students and fell by 2.7 times among those attending 9-11 grades. Hypermetropia fell oneway and myopia frequency grew one-way from the $1^{\text {st }}$ grade to $9-11^{\text {th }}$.

Bearing in mind that senior schoolchildren spend 2.7 times more tome using digital 
devices than first-grade pupils $(p=0.044)$, a period of time during which various digital devices are used can be considered a risk factor that causes myopia occurrence in schoolchildren. Relative risk (RR) calculation revealed that in case digital devices are used for 6 hours a day or longer, there is 1.8 times higher risk of myopia occurrence (RR 1.8; $95 \%$ CI 1.21-3.61, $p<0.05$ ).

\section{Conclusions.}

1. All schoolchildren use digital devices quite intensely, $\mathrm{PC}$ and mobile phones being the most frequently used ones. A number of used digital devices grows with age, from 1.8 per a 1 first-grade pupil to 2.6 per a fifthgrade student and 2.3 per a senior schoolchild. Average time spent on using digital devices per day also grows from 3 hours for first-grade pupils to 8.1 hours a day per senior schoolchildren.

2. Most schoolchildren suffer from diseases of the eye and adnexa, in particular refraction and accommodation disorders; accommodation disorders prevail among firstgrade pupils where as myopia is the most widely spread disease among fifth-grade students and senior schoolchildren. A number of children with myopia grows by 2.1 times from the $1^{\text {st }}$ grade to senior school.

3. Use of digital devices for 6 hours a day or longer results in a 1.8 times higher risk of myopia.

Funding. The research was not granted any sponsor support.

Conflict of interests. The authors declare there is no any conflict of interests.

\section{References}

1. Luk'yanets G.N., Makarova L.V., Paranicheva T.M., Tyurina E.V., Shibalova M.S. Vliyanie gadzhetov na razvitie detei [Influence exerted by gadgets on children's development]. Novye issledovaniya, 2019, no. 1 (57), pp. 25-35 (in Russian).

2. Shabunova A.A., Korolenko A.V. Children's involvement in digital space: gadgetization trends and threats to human development. Vestnik Udmurtskogo universiteta. Sotsiologiya. Politologiya. Mezhdunarodnye otnosheniya, 2019, vol. 3, no. 4, pp. 430-443 (in Russian).

3. Korolenko A.V., Gordievskaya A.N. Human potential of the child population: understanding and assessment. Sotsial'noe prostranstvo, 2018, no. 5 (17), pp. 3 (in Russian).

4. Ravichandran P., De Bravo B.-F., Beauport R. Young children and screen time (TV, Computers, etc.). Washington, National Center for Health Research Publ., 2019, pp. 223-400 (in Russian).

5. Subrahmanyam K., Kraut R.E., Greenfield P.M., Gross E.F. The impact of home computer uses on children's activities and development. Future Child, 2011, no. 10, pp. 123-144 (in Russian).

6. Usol'tseva D.D. Vliyanie sovremennykh gadzhetov na zdorov'e shkol'nikov [Effects produced by modern gadgets on schoolchildren's health]. Rossiiskaya akademiya estestvoznaniya, 2017. Available at: https://school-science.ru/3/1/32591 (03.06.2020) (in Russian).

7. Zubarev Yu.B. Mobil'nyi telefon i zdorov'e: monografiya [A mobile phone and health: a monograph]. $4^{\text {th }}$ edition. Moscow, Biblio-Globus Publ., 2019, 234 p. (in Russian).

8. Sundus M. The impact of using gadgets on children. Journal of Depression and Anxiety, 2018, vol. 7, no. 1, pp. 3. DOI: $10.4172 / 2167-1044.1000296$

9. Woo E.H., White P., Lai C.W. Impact of information and communication technology on child health. J Paediatr Child Health, 2016, vol. 6, no. 52, pp. 590-594. DOI: 10.1111/jpc.13181

10. Kuchma V.R., Tkachuk E.A., Tarmaeva I.Yu. Psychophysiological state of children in conditions of informatization of their life activity and intensification of education. Gigiena i sanitariya, 2016, vol. 95, no. 12, pp. 1183-1188 (in Russian).

11. Borisova O.S., Sitinova A.A., Duisenbek F.N. Vliyanie komp'yutera na zdorov'e i psikhiku uchenikov [Impacts exerted by a PC on schoolchildren's health and mind]. Integratsiya psikhologopedagogicheskikh nauk i aktual'nykh obrazovatel'nykh praktik: sbornik trudov mezhdunarodnoi studencheskoi nauchno-prakticheskoi ochnoi konferentsii. Moscow, 2019, pp. 43-48 (in Russian).

12. Soltan M.M., Titova D.A., Shemetovets T.N. Donozologicheskaya diagnostika bezopasnosti tsifrovoi sredy dlya psikhicheskogo zdorov'ya podrostkov [Pre-nosologic diagnostics of digital environment safety for teenagers' mental health]. Sovremennaya model' meditsinskogo obespecheniya detei v obrazovatel'nykh organizatsiyakh: Materialy VI Natsional'nogo kongressa po 
shkol'noi i universitetskoi meditsine. Ekaterinburg, Izdatel'stvo UGMU Publ., 2018, vol. 6, pp. 195-196 (in Russian).

13. Galuzo I.V. Nuzhny li mobil'nye ustroistva $v$ uchebnom protsesse? [Are mobile devices truly necessary for educational process?]. Sovremennoe obrazovanie Vitebshchiny, 2020, no. 1 (27), pp. 26-35 (in Russian).

14. Abdullina A.M. The impact of computer on sight. Prioritetnye zadachi i strategii razvitiya pedagogiki i psikhologii: sbornik nauchnykh trudov po itogam mezhdunarodnoi nauchno-prakticheskoi konferentsii. Moscow, 2017, pp. 37-39 (in Russian).

15. San'kov S.V., Kuchma V.R. Hygienic assessment of the impact of the modern schools' electronic information-educational environment on children. Vestnik novykh meditsinskikh tekhnologii. Elektronnoe izdanie, 2019, no. 3, pp. 98-103 (in Russian).

16. Platonova A.G., Yatskovskaya N.Ya., Dzhurinskaya S.N., Shkarban E.S., Saenko G.M. Psikhoemotsional'noe sostoyanie shkol'nikov pri ispol'zovanii noutbuka i plansheta $\mathrm{v}$ protsesse obucheniya [Psychoemotional state of schoolchildren while using a laptop or a pad in educational process]. Okhrana zdorov'ya i bezopasnost' zhiznedeyatel'nosti detei i podrostkov. Aktual'nye problemy, taktika i strategiya deistvii: Materialy IV Vserossiiskogo kongressa po shkol'noi i universitetskoi meditsine s mezhdunarodnym uchastiem. Sankt-Peterburg, 2014, pp. 262-264 (in Russian).

17. Maducdoc M.M., Haider A., Nalbandian A., Youm J.H., Morgan P.V., Crow R.W. Visual consequences of electronic reader use: a pilot study. Int Ophthalmol, 2017, no. 37 (2), pp. 433-439. DOI: $10.1007 / \mathrm{s} 10792-016-0281-9$

18. Porcar E., Pons A.M., Lorente A. Visual and ocular effects from the use offlat-panel displays. Int J Ophthalmol, 2016, vol. 9, no. 6, pp. 881-885. DOI: 10.18240/ijo.2016.06.16

19. Stepanova M.I., Aleksandrova I.E., Sazanyuk Z.I., Voronova B.Z., Lashneva I.P., Shumkova T.V. Hygienic regulation of the use of electronic educational resources in the modern school. Gigiena i sanitariya, 2015, vol. 94, no. 7, pp. 64-68 (in Russian).

20. Kuchma V.R., Tkachuk E.A., Efimova N.V. Hygienic assessment of the intensification of educational activity of children in modern conditions. Voprosy shkol'noi i universitetskoi meditsiny $i$ zdorov'ya, 2015, no. 1, pp. 4-11 (in Russian).

21. Kuntysh S.A., Gribushkin I.Yu., Kholopov E.G., Moskalenko M.A. IT tekhnologii v obshcheobrazovatel'nykh uchebnykh zavedeniyakh [IT in secondary schools]. Materialy vtoroi mezhregional'noi nauchno-prakticheskoi konferentsii prepodavatelei matematiki i fiziki pod devizom «Matematika - eto prosto!». Sankt-Peterburg, 2020, pp. 71-75 (in Russian).

22. Gaiduchenok A.K. Profilaktika gadzhetozavisimosti i obespechenie bezopasnosti shkol'nikov $\mathrm{v}$ internete $\mathrm{v}$ rabote shkoly [Preventing gadget-dependence and providing safety for schoolchildren in the Internet used in educational process in school]. Tsifrovaya transformatsiya obrazovaniya: Elektronnyi sbornik tezisov nauchno-prakticheskoi konferentsii. Minsk, 2018, pp. 67-68 (in Russian).

Filkina O.M., Vorobyova E.A., Dolotova N.V., Kocherova O.Yu., Malyshkina A.I. Long use of digital devices as a risk factor that causes myopia occurrence in schoolchildren. Health Risk Analysis, 2020, no. 4, pp. 77-84. DOI: 10.21668/health.risk/2020.4.08.eng

Received: 17.06 .2020

Accepted: 24.11.2020

Published: 30.12.2020 